ISSN : 2303-1514 | E-ISSN : 2598-5949

\title{
TEACHERS' COMPETENCE IN THE DOMAIN OF LEARNING FACILITY BASED ON EDUCATION FOR SUSTAINABLE DEVELOPMENT
}

\author{
Mia Azzahra ${ }^{1}$, Ghullam Hamdu ${ }^{2}$ \\ ${ }^{1,2}$ Universitas Pendidikan Indonesia, Indonesia \\ 1miaazzahra1609@gmail.com, ${ }^{2}$ ghullamh2012@upi.edu
}

\section{KOMPETENSI GURU PADA DOMAIN FASILITAS PEMBELAJARAN BERBASIS PENDIDIKAN UNTUK PEMBANGUNAN BERKELANJUTAN}

\begin{tabular}{|c|c|}
\hline ARTICLE HISTORY & ABSTRACT \\
\hline $\begin{array}{l}\text { Submitted: } \\
\text { 06 Juni } 2021 \\
\text { 06 }{ }^{\text {th }} \text { June } 2021\end{array}$ & $\begin{array}{l}\text { Abstract: Teachers are an important component in determining the learning process in } \\
\text { Education for Sustainable Development (ESD). The second report of the teacher education } \\
\text { project for ESD Asia - Pasific held on } 17^{\text {th }}-19^{\text {th }} \text { September } 2019 \text { in Bangkok produced a } \\
\text { competency framework for ESD teachers. This framework defines the competencies required by } \\
\text { teachers to be involved in ESD which are implemented, developed, and evaluated by teacher } \\
\text { education institutions. There are three domains in the teacher competency framework for ESD: } \\
\text { facilitate learning, continue to learn and create, as well as connect, collaborate, and engage. } \\
\text { However, this study only focused on one domain, which was learning facility. A total of } 25 \\
\text { teachers from nine elementary schools provided their best answers based on the existing reality } \\
\text { through a questionnaire distributed by the researchers about ESD-based teacher competence } \\
\text { in the domain of lthe earning facility. This study aimed to determine the extent to which } \\
\text { teachers understand and implement ESD-based competence in the domain of learning facilities } \\
\text { in elementary schools. The data were processed with the rasch model through the winsteps } \\
\text { application. The results of this study indicated that the teachers were able to implement it very } \\
\text { well, but the idea was that the teachers still did not know that what they did led to ESD-based } \\
\text { teachers' competence in the domain of learning facility. }\end{array}$ \\
\hline
\end{tabular}

Accepted:

09 September 2021

$09^{\text {th }}$ September 2021

Published:

26 Oktober 2021

$26^{\text {th }}$ October 2021
Keywords: teachers' competence, rasch model

Abstrak: Melaksanakan Education for Sustainable Development (ESD), guru menjadi komponen penting dalam menentukan proses pembelajaran. Pada laporan kedua proyek pendidikan guru untuk ESD wilayah Asia - Pasifik yang diselenggarakan 17 - 19 September 2019 di Bangkok, menghasilkan kerangka kerja kompetensi guru ESD. Kerangka kerja ini telah menetapkan kompetensi yang diperlukan oleh guru guna terlibat dalam ESD yang diimplementasikan, dikembangkan dan dievaluasi oleh lembaga pendidikan guru. Dalam kerangka kerja kompetensi guru untuk ESD terdapat tiga domain, yaitu; a. facilitate learning, b. continue to learn and creat, serta c. connect, collaborate, and engage Namun, penelitian ini hanya fokus pada satu domain yaitu facilitate learning. Sebanyak 25 guru di sembilan Sekolah Dasar (SD) telah memberikan jawaban terbaik mereka sesuai dengan kenyataan yang ada melalui angket yang disebarkan oleh peneliti mengenai topik pembahasan yaitu kompetensi guru berbasis ESD pada domain fasilitas pembelajaran. Penelitian ini bertujuan untuk melihat sejauh mana pemahaman dan pengimplementasian guru di SD terkait fokus penelitian ini. Data yang diperoleh kemudian diolah dengan rasch model melalui aplikasi winsteps. Hasil penelitian ini menunjukkan bahwasanya guru mampu mengimplementasikan dengan sangat baik namun secara gagasanya guru masih belum mengetahui bahwa yang dilakukan sudah mengarahkan pada kompetensi guru berbasis ESD pada domain facilitate learning.

Kata Kunci: kompetensi guru, model rasch

\section{CITATION}

Azzahra, M., \& Hamdu, H. (2021). Teachers' Competence in the Domain of Learning Facility Based on Education for Sustainable Development. Primary: Jurnal Pendidikan Guru
Sekolah
Dasar
10
(5),
1104-1117.
DOI: 


\section{PENDAHULUAN}

Pembangunan Berkelajutan (PB) atau Sustainable Development (SD), disajikan pusat pembahasan dalam laporan komisi World Environment and Development (WCED) Perserikatan Bangsa - Bangsa (PBB). Dimana Our Common Future yang disebut juga laporan Brundtland oleh ketua Gro Harlem Brundtland (mantan perdana Menteri di Norwegia). Tahun 1987, pertama kali saat itu diperkenalkan dalam sidang umum PBB, bahwa pembangunan berkelanjutan memiliki makna sebagai prinsip dari pengorganisasian pembangunan manusia untuk memenuhi kebutuhan dalam jangka waktu yang panjang. PBB membagi tiga dimensi dalam pembangunan berkelanjutan yaitu lingkungan, sosial dan ekonomi. Tahun 1992 PBB melaksanakan konferensi mengenai lingkungan dan pembangunan di Rio de Janeiro, Brazil. Pembahasan dalam konferensi ini adalah menyerukan bahwa BAB 36 agenda 21, pendidikan harus diarahkan pada pembangunan berkelanjutan. Bab ini memperjelas mengenai empat dorongan utama memulai pekerjaan Pendidikan Pembangunan Berkelanjutan (PPB) atau Education for Sustainable Development (ESD) yaitu meningkatkan pendidikan dasar, mengarahkan kembali pendidikan ke pembangunan berkelanjutan, mengembangkan pemahaman dan kesadaran public, serta latihan (Glavic, 2020).

Pengakuan secara internasional mengenai ESD ini sebagai pendorong utama dalam pembangunan berkelanjutan telah melalui tiga pertemuan secara global, yaitu pertama konferensi PBB pada tahun 1992 mengenai lingkungan dan pembangunan (UNCED) di Rio de Janeiro, kedua yaitu Konferensi Tingkat Tinggi (KTT) Dunia pada tahun 2002 mengenai Pembangunan Berkelanjutan (WSSD) di Johannesburg, Afrika Selatan, ketiga Konferensi PBB pada tahun 2012 mengenai Pembangunan Berkelanjutan (UNCSD) di Rio de Janeiro,
Brazil. Disamping itu pula, ESD diakui dalam perjanjian global utama lainnya seperti Perjanjian Paris pada pasal 12 (UNESCO, 2017).

Tanggal 25 September 2015 PBB mendeklarasikan Sustainable Development Goals (SDGs) melalui siding umum dimana mengadopsi dari agenda 2030, yang berlangsung di Rio de Janeiro pada Juni 2012. Selama tiga tahun melibatkan negara - negara anggota PBB sebanyak 193 negara, survei nasional yang melibatkan jutaan orang. Agenda 2030 berintikan 17 tujuan pembangunan berkelanjutan (SDGs) yang transformasional, inklusif dan universal menggambarkan tantangan pembangunan berkelanjutan yang sejahtera, damai dan adil sehingga menjadikan bumi yang layak ditempati untuk semua orang baik sekarang maupun dalam jangka waktu yang panjang. Tujuan ini memuat tatangan global yang sangat penting untuk keberlangsungan hidup manusia, 17 tujuan ini yaitu; tanpa kemiskinan, tanpa kelaparan, kesehatan dan kesejahteraan yang baik, pendidikan berkualitas, kesetaraan gender, air bersih dan sanitasi, energi terjangkau dan bersih, pekerjaan yang layak dan pertumbuhan ekonomi industri, inovasi dan infrastruktur, mengurangi ketimpangan, kota dan komunitas berkelanjutan, konsumsi dan produksi yang bertanggungjawab, aksi iklim, kehidupan di bawah air, kehidupan di darat, perdamaian, keadilan dan institusi kuat, kemitraan untuk tujuan (UNESCO, 2018).

SDGs memegang prinsip "No one left behind" and "We're all part of this", dimana artinya tidak seorangpun tertinggal dibelakang dan semua lapisan masyarakat menjadi bagian dari tujuan tercapainya SDGs., semua harus saling berdampingan satu sama lain sebagai bukti perjalanan bersama sejumlah negara. Pada poin empat dalam tujuan SDGs mengenai pendidikan berkualitas untuk mewujudkan hal tersebut maka ESD disini memiliki peran, sebab diakui sebagai bagian penting atau kunci dari pendidikan berkualitas sekaligus 
pendukung penting dalam pembangunan berkelanjutan. Jika ingin memperbaiki suatu system dalam negara maka perbaiki pendidikanya, hal inilah yang menjadi alas an ESD penting dan selalu mengalami perkembangan dari masa ke masa.

Dalam melaksanakan ESD maka perlu adanya proses pembelajaran berlangsung, dimana ada guru dan siswa di dalamnya. Guru menjadi komponen penting dalam menentukan proses pembelajaran. Pada laporan kedua proyek pendidikan guru untuk ESD wilayah Asia - Pasifik yang diselenggarakan 17 - 19 September 2019 di Bangkok, menghasilkan kerangka kerja kompetensi guru ESD. Kerangka kerja ini telah menetapkan kompetensi yang diperlukan oleh guru guna terlibat dalam ESD yang diimplementasikan, dikembangkan dan dievaluasi oleh lembaga pendidikan guru. Hasil ini kemudian diumumkan di Okayama, Jepang pada November 2019 pada "Konferensi Global 2019 tentang Pendidikan Guru untuk ESD", dihadiri oleh 250 peserta dari 40 negara. Dalam kerangka kerja kompetensi guru untuk ESD terdapat tiga domain, yaitu; a. facilitate learning, b. continue to learn and creat, serta c. connect, collaborate, and engage (UNESCO, 2020). Indonesia turut serta dalam keaanggotaan $\mathrm{PBB}$, sehingga program dunia yang telah dirancang dan disahkan ini Indonesia berkontribusi di dalamnya, dihadiri oleh Wakil Presiden Jusuf Kalla pada saat itu. Indonesia memiliki target pada 2030, memastikan bahwa semua peserta didik memperoleh pengetahuan dan keterampilan yang dibutuhkan untuk mempromosikan pembangunan berkelanjutan termasuk tentang ESD, HAM, dan kesetaraan gender (Jagtap, 2016).

Guru memiliki banyak peran di kelas, salah satunya adalah sebagai fasilitator, dan dalam kurikulum 2013 yang berlaku saat ini di Indonesia sedang dikembangkan dimana pembelajaran berfokus pada peserta didik yang aktif berdasarkan pemikiran kritis dan pengalaman, sehingga dalam kurikulum ini peran guru lebih ditekankan sebagai fasilitator (Rahmawati \& Suryadi, 2019). Guru sebagai fasilitator di sini bertanggung jawab untuk meninjau proses pembelajaran secara keselruhan hingga memberikan ruang kepada peserta didik untuk menerima pembelajaran dengan optimal dengan mengurangi sedikit demi sedikit kebingungan yang mereka miliki (Poekert, 2011). Yang artinya, guru sebagai penyedia segala fasilitas pembelajaran, hal ini sangat penting dalam melaksanakan pendidikan pembangunan berkelanjutan dan sebagaimana telah disebutkan pada "Konferensi Global 2019 tentang Pendidikan Guru untuk ESD” bahwasanya guru sebagai fasilitator memudahkan pembelajaran bagi peserta didik. Dengan demikian, topik pembahasan kompetensi guru berbasis Education for Sustainable Development (ESD) dalam memberikan fasilitas pembelajaran sangat penting untuk dibahas. Hal ini untuk melihat sejauh mana pemahaman dan pengimplementasian kompetensi guru berbasis ESD pada domain facilitate learning.

\section{KAJIAN TEORI}

Pendidikan menjadi instrumen penting dalam proses pembangunan berkelanjutan, sebab menjadi pemikiran sejak awal dimana secara generalisasi dapat dinyatakan bahwa ESD mencakup segala jenis konsep, tahapan dan proses pendidikan yang relevan dalam membina kontribusi baik secara individu maupun kelompok menuju pembangunan berkelanjutan. ESD dianggap mampu untuk mewujudkan tujuan tersebut, selain itu pula ESD bisa menjadi pendorong utama dalam pencapaian tujuan lainnya, hal ini karena pendidikan mampu untuk menopang segala aspek dalam hal memperbaiki hingga meningkatkan hasil. Kompetensi yang lebih tinggi seperti kreativitas, kemampuan bertindak, pemikiran yang berorientasi pada solusi merupakan hal mendasar bagi ESD, sebab jika tidak ada hal tersebut makan tidak mungkin menemukan cara, konsep, teknik yang dapat membuat sebuah keberhasilan 
mencapai pada ruang berkelanjutan. UNESCO pada tahun 2017 menerbitkan delapan kompetensi setelah melakukan diskusi intensif selama dua dekade, kompetensi tersebut ialah kompetensi berpikir kritis, kompetensi antisipatif, kompetensi normatif, kompetensi srategis, kompetensi kolaborasi, kompetensi kesadaran diri, kompetensi pemecahan masalah, kompetensi berpikir sistem. Dengan ini indikator global menyerukan kepada ESD agar pelaksanaanya mengurus hal - hal yang utama seperti kurikulum, pendidikan guru dan kebijakan pendidikan, Curriculum Framework ESD melibatkan 21 bidang tematik yang dianggap sesuai dengan tiga dimensi (sosial, ekonomi dan lingkungan) yang telah ditetapkan oleh PBB dalam pelaksanaan SDGs ini, yaitu, keanekaragaman nilai, budaya dan kondisi kehidupan, globalisasi prinsip - prinsip pedoman agama dan etika, pangan dan pertanian, kesehatan, pendidikan, perlindungan, dan penggunaan sumber daya alam, dan pembangkitan energi, perubahan lingkungan global. (Hoffmann \& Siege, 2018).

Di Jepang, tepatnya kantor Direktur Jenderal Urusan Internasional di MEXT memberikan tanggapan mengenai rekomendasi dengan pembuatan panduan promosi ESD, guna mencapai implementasi ESD di sekolah, Tujuan dari panduan ini untuk memberikan informasi mengenai pentingnya ESD serta sebagai cara yang praktis untuk menetapkan ESD di sekolah kepada guru yang belum terbiasa dengan ESD. Rencana implementasi ESD di Jepang mengatakn bahwa "ESD sebagai pembelajaran dan kegiatannya berdasarkan pada pendekatan berpikir global serta bertindak secara lokal, dengan tujuan mengembangkan nilai serta perilaku baru yang akhirnya akan mengarahkan pada solusi bagi permasalahan yang dihadapi dalam kehidupan bermasyarakat berkelanjutan".Jepang juga menggunakan istilah lain dari ESD yaitu "Belajar untuk bumi yang lebih baik", hal ini bisa menjadikan kesan lebih santai dan tidak terlihat kaku dikalangan peserta didik. Poin utama dalam menerapkan ESD adalah perlu dibuatnya relevansi antara peserta didik dengan lingkungan sekolah (Japan National Commission for UNESCO, 2016).

Pengimplementasian di Indonesia juga masih terus dilakukan. Pada usia ini, anak pendidikan dasar sedang berada pada tahap berpikir operasional konkret serta ada pada masa Golden Age, dengan keberagamannya (learner diversity) (Mustadi \& Senen, 2018). Tentunya dalam hal ini membutuhkan keterampilan dalam kompetensi guru untuk menghubungkan indikator yang dibuat dengan ESD. Tahun 2018 - 2019, para peserta proyek "Pendidikan Guru untuk ESD di Wilayah Asia - Pasifik" dari tahap manajemen senior lembaga pendidikan guru dan pejabat Kementerian Pendidikan yang membidangi pertemuan regional tentang pendidikan guru di 16 negara pada Kawasan Asia - Pasifik mengikuti pertemuan regional tentang pendidikan guru ESD sebanyak dua kali yaitu di Okiyama, Jepang dan Bangkok, Thailand serta pertemuan persiapan di Bandung, Indonesia. Pada pertemuan tersebut menghasilkan "Kerangka Kerja Kompetensi Guru ESD Asia - Pasifik", dengan menghasilkan tiga domain penting yaitu, a. facilitate learning, $b$. continue to learn and creat, c. connect, collaborated, and engage. Peraihan ini diumumkan pada "Konferensi Global 2019 tentang Pendidikan Guru untuk ESD" yang diselenggarakan di Okayama, Jepang pada November 2019, diikuti oleh 250 peserta dan 40 negara yang sangat berkontribusi.

Guru sebagai fasilitator dalam pembelajaran maka artinya guru memberikan fasilitas untuk memudahkan peserta didik dalam memahami suatu pembelajaran. Dengan demikian, fokus pembahasan artikel ini ada pada domain facilitate learning. Pada domain ini diharapkan mampu menciptakan dan memberikan kesempatan belajar kepada peserta didik guna mengembangkan kemampuan keberlanjutan yang mereka miliki. Domain facilitate learning membahas 
mengenai menciptakan pembangunan berkelanjutan, didasarkan pada pengetahuan, keterampilan dan penggunaan yang memiliki keterhubungan dengan "Pedagogi (Bagaimana cara mengajar)", "Teknologi (Alat instruksional apa yang digunakan?)", "Konten (Apa yang diajarkan?)". Dimana ketiga aspek ini saling berhubungan dan dalam melasanakannya disesuaikan dengan budaya di negara tersebut (UNESCO, 2020).

Domain facilitate learning, pada aspek budaya diposisikan untuk kewarganegaraan global guna pembangunan berkelanjutan dengan memperhatikan pribadi dan kesejahteraan keluarga, kerjasama antar budaya dan perdamaian, internasional, mengubah sikap dan gaya hidup. Aspek pedagogi di sini membahas cara mengajar seorang guru dengan mengetahui rencana pembelajaran pedagogi ESD, memiliki toleransi dengan ketidakpastian, merencanakan dan menerapkan pedagogi pengajaran yang relevan dan tepat yang menanggapi kebutuhan peserta didik, berkolaborasi dengan pemangku kepentingan internal dan eksternal dalam implementasi, pemantauan dan penilaian pedagogi ini. Aspek teknologi membahas mengenai alat instruksional yang digunakan sebagai fasilitas pembelajaran dengan memahami prinsip - prinsip dasar dari teknologi yang relevan, menggunakan teknologi yang tepat untuk memfasilitasi pembelajaran peserta didik. Aspek isi membahas mengenai hal - hal yang akan dipelajri dengan menetapkan tujuan pembelajaran, melihat dan menemukan masalah dan masalah yang saling berkaitan, mendorong peserta didik untuk mengajukan pertanyaan dan konteks situasi nyata untuk keberlanjutan.

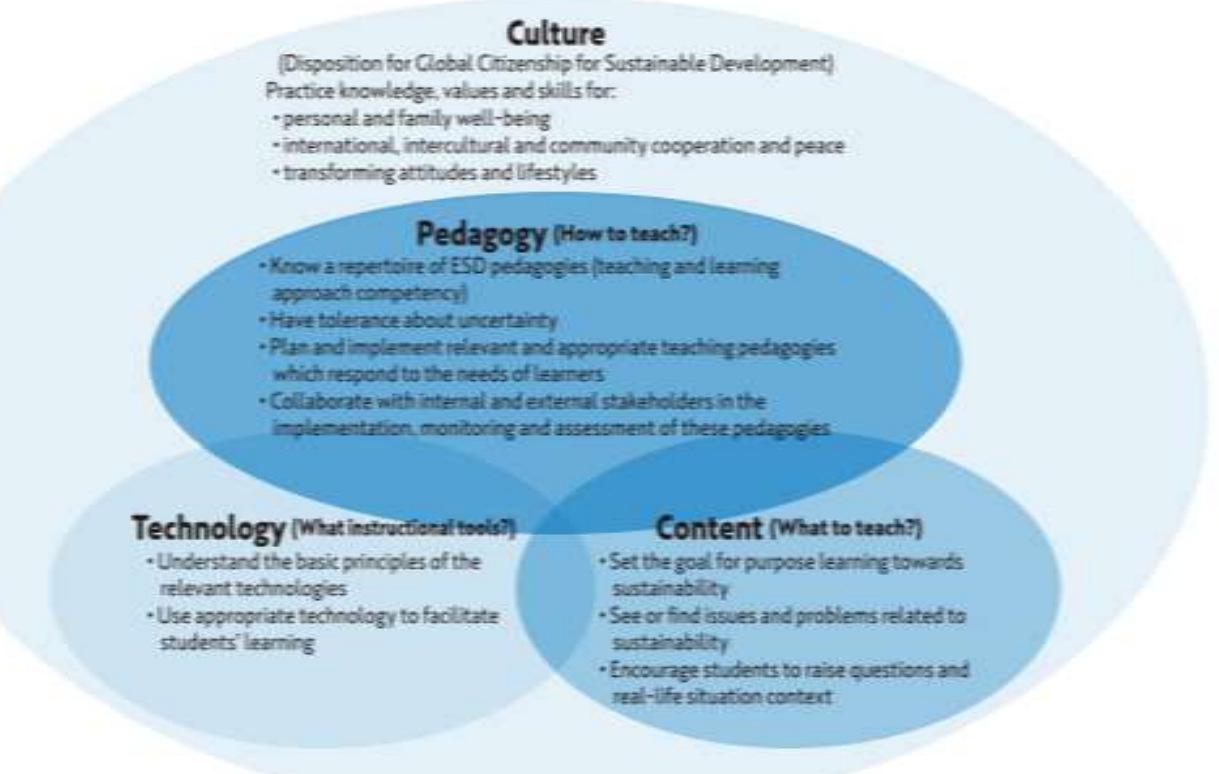

Gambar 1. Domain Facilitate Learning

\section{METODE PENELITIAN}

Peneliti menggunakan angket sebagai daftar pernyataan yang akan ditanggapi oleh responden. Angket yang digunakan dalam penelitian ini adalah angket tertutup, dimana responden menjawab setiap pernyataan sesuai dengan jawaban yang telah disediakan namun responden bebas memilih diantara jawaban yang telah tersedia. Untuk itu peneliti mengunakan rating scale agar responden dapat memilih salah satu (sering, selalu, jarang, tidak pernah melaksanakan) mengenai suatu 
penyataan dalam angket penelitian (Priatna, 2008). Tujuan angket ini diberikan kepada responden adalah untuk melihat sejauh mana pemahaman dan pengimplementasian kompetensi guru berbasis ESD pada domain facilitate learning.

Angket yang disebarkan ada yang berupa cetak dan link google form. Peneliti menyebarkan angket kepada responden yaitu guru - guru Sekolah Dasar (SD) yang menjadi guru kelas rendah dan tinggi, dengan meminta informasi tambahan mengenai masa lama mengajar, kemudian melihat tempat mengajarnya kabupaten dan kota. Pelaksanaan penelitian berlangsung dari tanggal $6 \mathrm{Mei}-18$ Mei 2021 dengan hasil angket yang dicetak diisi oleh guru sebanyak 11 orang dan 14 guru yang telah mengisi angket melalui google form. Sehingga, ada 25 guru sebagai responden di sembilan Sekolah Dasar (SD) yang telah memberikan jawabannya melalui angket penelitian tersebut. Hasil dari jawaban responden akan diolah menggunakan rasch model dengan aplikasi winsteps.

\section{HASIL DAN PEMBAHASAN}

Penelitian ini telah membentuk Focus Group Discussion (FGD) untuk membahas kompetensi guru berbasis Education for Sustainable Development (ESD). Dalam hal ini, permasalahan yang dihadapi adalah keingintahuan mengenai pemahaman dan pengimplementasian ESD dalam pembelajaran yang dilaksanakan guru. Oleh sebab itu instrumen penelitian yang dirancang dalam bentuk angket dibuat oleh FGD bersama tim research untuk memvalidasi dari tata bahasa yang digunakan, kemudian keterhubungan dengan ESD pada domain fasilitas mengajar. Untuk reliabilitas dilihat melalui aplikasi Winstep. Ketika instrumen penelitian yang dirancang dalam bentuk angket ini sudah melalui tahapan tersebut, maka angket layak untuk disebar dalam bentuk cetak dan link google form. Sampai pada tahap penyebaran angket hingga akhirnya mendapatkan 25 responden (11 mengisi angket dalam bentuk cetak dan 14 mengisi melalui link google form) yaitu guru dari berbagai kelas baik kelas rendah maupun tinggi, dan dari sembilan sekolah baik yang di kabupaten (5 SD) maupun di kota (4 SD). Data yang diperoleh melalui 25 responden ini kemudian diolah melalui aplikasi Winsteps menggunakan rasch model.

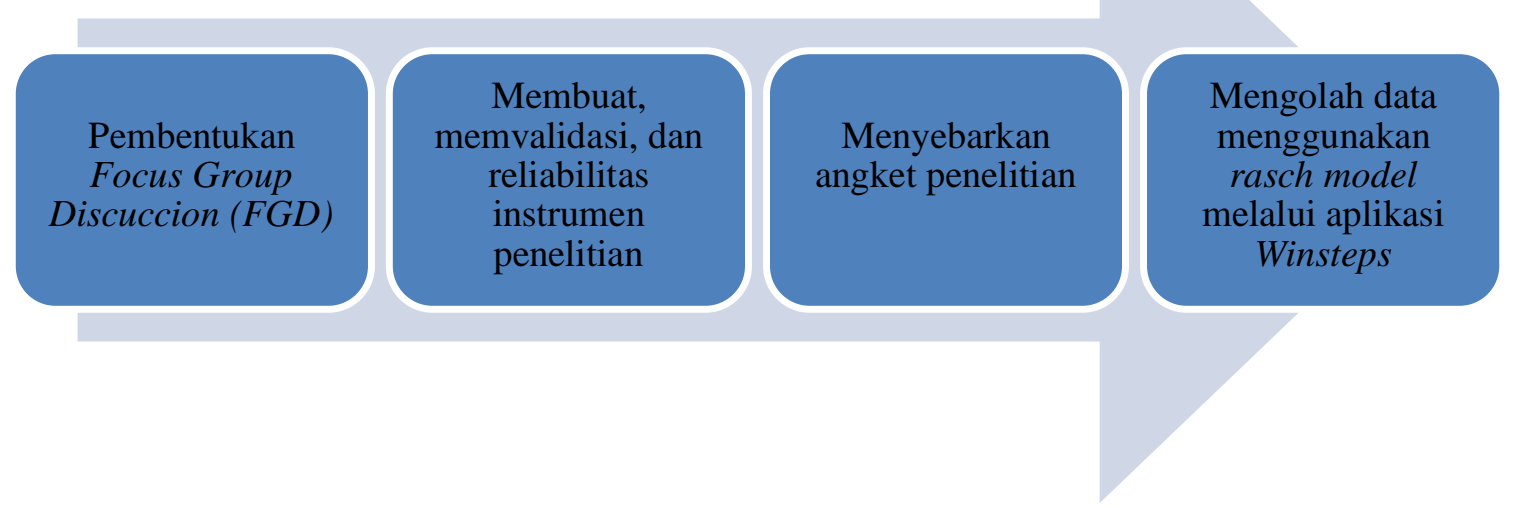

Gambar 2. Tahapan penelitian 
ISSN : 2303-1514 | E-ISSN : 2598-5949

DOI : http://dx.doi.org/10.33578/jpfkip.v10i5.8321

https://primary.ejournal.unri.ac.id/index.php/JPFKIP

Hasil olah data melalui aplikasi

A. Analisis Pernyataan Sukar dilaksanakan Winsteps diperoleh sebagai berikut :

Tabel 1. Kompetensi Guru Berbasis ESD Domain Fasilitas Pembelajaran Berdasarkan Analisis Pernyataan Sukar Dilaksanakan

\begin{tabular}{|c|c|c|c|c|c|c|c|c|c|c|c|}
\hline $\begin{array}{l}\text { Nomor } \\
\text { Pernyataa } \\
\text { n }\end{array}$ & 5 & 7 & 8 & 1 & 2 & 11 & 4 & 6 & 9 & 10 & 3 \\
\hline Measure & 2.27 & 1.83 & 0.10 & 0.01 & -0.08 & -0.18 & -0.28 & -0.59 & -0.70 & $\begin{array}{c}- \\
0.70\end{array}$ & $\begin{array}{c}- \\
1.69\end{array}$ \\
\hline $\begin{array}{l}\text { Item } \\
\text { Rata - Rata } \\
\text { SD }\end{array}$ & Q5 & Q7 & Q8 & Q1 & Q2 & $\begin{array}{l}\text { Q11 } \\
0.00 \\
1.08\end{array}$ & Q4 & Q6 & Q9 & Q10 & Q3 \\
\hline
\end{tabular}

Dari tabel di atas dapat diketahui bahwa SD (Standar Deviasi) sebesar 1.08. Jika nilai SD dikombinasikan dengan hasil logit kemudian diikuti kriteria, maka dihasilkan: a) Sangat sulit dilaksanakan jika nilai $>1.08$, b) Sulit dilaksanakan jika nilai berada diantara 0.00 hingga 1.08, c) Mudah dilaksanakan jika nilainya antara -1.08 hingga 0.00 , dan d) Sangat mudah dilaksanakan jika nilainya >1.08. Artinya dari Tabel 1, menginformasikan bahwa: a) Kategori pernyataan sangat sulit dilaksanakan terdapat pada nomor 5 (guru memfasilitasi pembeljaran dnegan berkolaborasi bersama para ahli dibidangnya masing - masing) dan 7 (pembelajaran menggunakan smartphone, laptop, proyektor, dalam menyampaikan materi yang sesuai untuk peserta didik), b) Kategori pernyataan sulit dilaksanakan ialah nomor 8 dan 1, c) Kategori pernyataan mudah dilaksanakan terdapat pada nomor 2, 11, 4, 6, 9, 10, dan d) Kategori pernyataan sangat mudah dilaksanakan adalah nomor 3 (guru merencanakan dan melaksanakan pembelajaran yang sesuai dengan kebutuhan peserta didik dan disampaikan secara menyeluruh melalui kerjasama dalam kelompok atau bermasyarakat, sehingga peserta didik dapat saling menghargai).

\section{B. Analisis Interaksi Responden dengan Instrumen}

Tabel 2. Kompetensi Guru Berbasis ESD Domain Fasilitas Pembelajaran Berdasarkan Summary of Measured Person and 11 Item

\begin{tabular}{lccc}
\hline \multicolumn{1}{c}{ Keterangan } & Nama Bagian & Person & Item \\
\hline \multirow{2}{*}{ Rata - Rata MNSQ } & INFIT & 1.05 & 0.94 \\
& OUTFIT & 0.95 & 0.95 \\
Rata - Rata ZSTD & INFIT & 0.15 & -0.34 \\
Rata - Rata Measure & OUTFIT & -0.05 & -0.28 \\
Separation & & 1.12 & 0.0 \\
Reliabilitas & & 1.19 & 2.99 \\
Cronbach Alpha & & 0.56 & 0.90 \\
\hline
\end{tabular}

Berdasarkan data yang telah tersedia dalam bentuk tabel di atas, dapat menginformasikan bahwa Cronbach Alpha memiliki nilai sebesar 0.64 yang artinya termasuk dalam kategori cukup. Reliabilitas responden 0.56 termasuk kategori lemah, artinya konsistensi jawaban dari responden lemah. Reliabilitas instrumen 0.90 termasuk dalam kategori bagus, artinya kualitas item item dalam instrumen sudah bagus dijadikan 
sebagai alat ukur dalam penelitian. Sangat penting untuk melihat nilai dari reliabilitas item penelitian atau pernyataan yang diajukan, sebab semakin tinggi nilai reliabilitasnya maka, semakin layak pula instrumen tersebut untuk digunakan sebagai alat ukur. Data lain yang dapat digunakan yaitu INFIT MNSQ dan OUTFIT MNSQ, untuk tabel person nilai rata - ratanya secara berurutan adalah 1,05 dan 0.95 , sedangkan untuk tabel item secara berurutan adalah 0.94 dan 0.95 nilai idealnya adalah 1.00 (berlaku untuk person dan item, semakin mendekati 1,00 maka akan semakin baik), untuk INFIT ZSTD dan OUTFIT ZSTD nilai rata - rata pada person secara berurutan ialah 0.15 dan -0.05 , sedangkan pada tabel item secara berurutan adalah -0.34 dan -0.28 dimana nilai idealnya adalah 0.00 (berlaku untuk person dan item semakin mendekati 0.00 maka semakin baik) (Sumintono \& Widhiarsono, 2015).

Pengelompokkan person dan item dapat diketahui dari nilai separasi, makin besar nilai separation (pemisah) maka kualitas instrumen dalam hal keseluruhan akan semakin bagus. Karena bisa mengidentifikasi kelompok responden dan kelompok item. Persamaan lain yang digunakan untuk melihat pengelompokkan secara lebih teliti disebut dengan pemisahan strata. Rumus yang dapat digunakan untuk menghitung separation yaitu, $\mathrm{H}=\{(4 \mathrm{x}$ separation $)+1\} / 3$, sehingga dari data tersebut dihasilkan bahwa separation person ialah 1.92 dibulatkan menjadi 2 . Sedangkan untuk separation item ialah 4.32 yang dibulatkan menjadi 4 (Abdul et al., 2020).

\section{Analisis Kemampuan Responden}

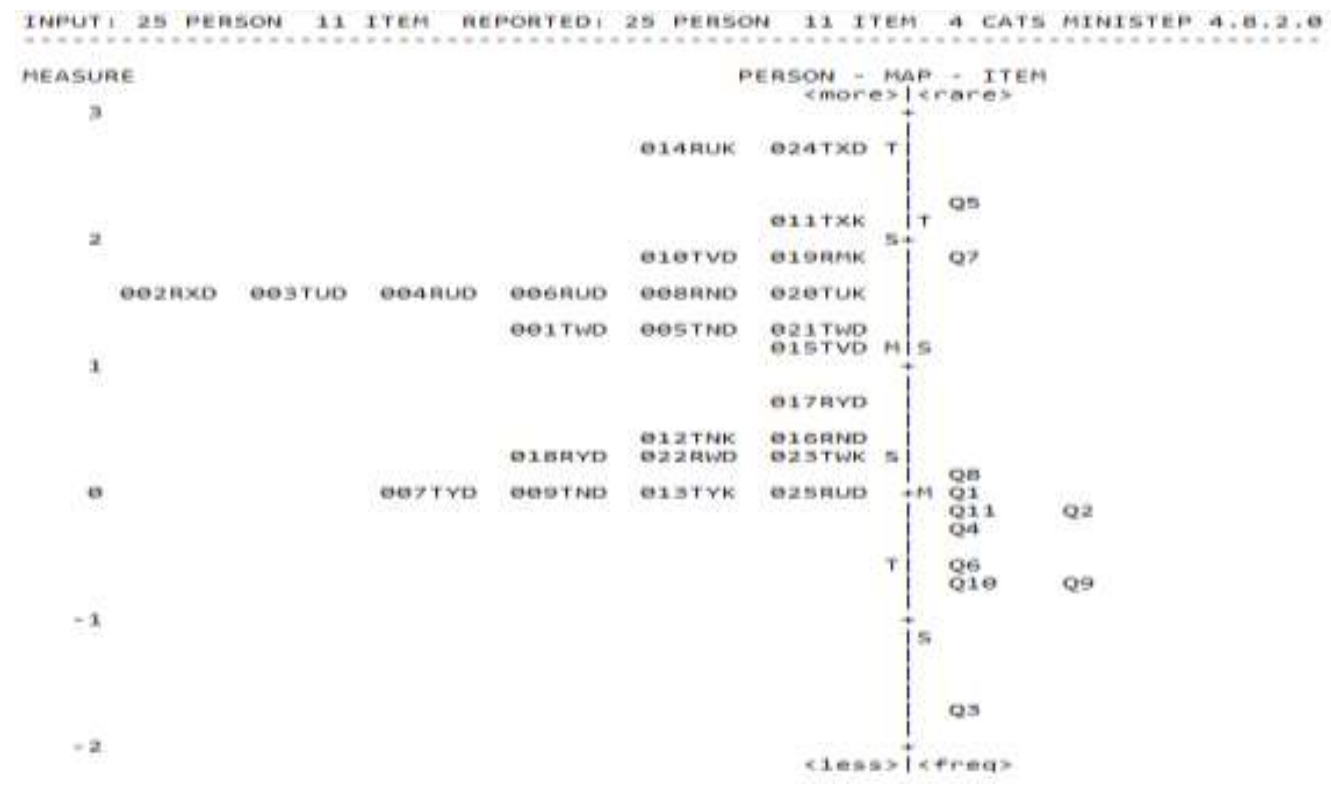

Gambar 3. Kompetensi Guru Berbasis ESD Domain Fasilitas Pembelajaran Berdasarkan Analisis Hasil Variabel Maps

Berdasarkan Tabel 2 diketahui bahwa rata - rata Person Measure ada pada logit $+1,12$. Artinya pada Gambar 3, ada 11 responden yang berada di bawah rata - rata (015TVD， 017RYD， 012TNK， 016RND, 018RYD, 022RWD, 023TWK, 007TYD,
009TND, 013TYK, 025RUD). Sedangkan 14 responden (021TWD, 005TND, 001TWD, 020TUK, 008RND， 006RUD， 004RUD, 003TUD, 002RXD, 019RMK, 010TVD, 011TXK, 024TXD, 014RUK) di atas logit 
+1.12 menunjukkan kecenderungan responden menjawab "Selalu Melaksanakan".

Responden dengan Person Measure tertinggi logit +2.75 adalah 024TXD (guru kelas VI dengan masa mengajar selama 27 tahun menjadikan banyak pengalaman mengajar dan mampu memfasilitasi pembelajaran dengan baik, terkhususnya pada penelitian ini dimana melihat pemahaman dan pengimplementasian fasilitas pembelajaran yang berbasiskan pada ESD, meskipun mengajar di kabupaten namun masih mampu memberikan fasilitas seoptimal mungkin, secara tidak langsung guru tersebut sudah memahami konsep fasilitas pembelajaran berdasarkan ESD serta sudah mengimplementasikannya, meskipun belum mengetahui mengenai ESD) dan 014RUK (guru kelas I dengan masa kerja 11 tahun dan mengajar di kota, kesempatan mengajar yang ditunjang oleh fasilitas mengajar yang sudah disediakan oleh sekolah, menjadikan guru lebih mudah untuk menginplementasikan fasilitas pembelajaran berdasarkan ESD, secara tidak langsung guru tersebut sudah memahami dan mengimplementasikan fasilitas pembelajaran berbasis ESD, meskipun belum mengetahui hal - hal mengenai ESD).

\section{Analisis Transposisi Data Menjadi Skalogram}

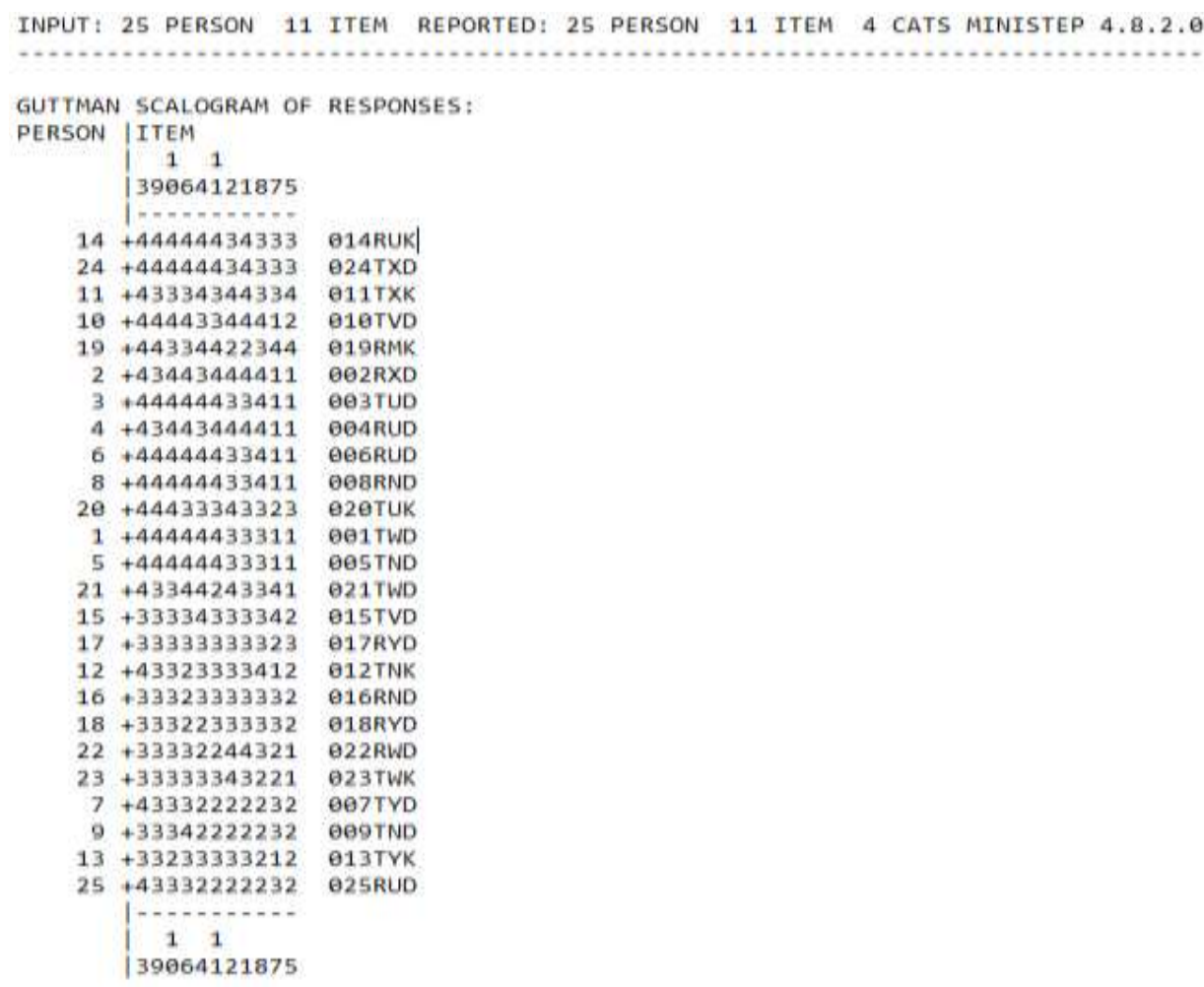

\section{Gambar 4. Skalogram}

Dengan matriks Guttman (biasa disebut skalogram), yang disusun berdasarkan dari tingkatan termudah ke yang tersulit, sedangkan untuk responden diurutkan dari yang paling mampu ke yang terendah
(Sumintono \& Widhiarso, 2013). Selain didapatkan informasi bahwa pernyataan yang mudah dilakukan oleh responden ada pada nomor 3, sedangkan pernyataan sulit dilakukan ada pada nomor 5. Pada Gambar 4 data yang 
ISSN : 2303-1514 | E-ISSN : 2598-5949

DOI : http://dx.doi.org/10.33578/jpfkip.v10i5.8321

https://primary.ejournal.unri.ac.id/index.php/JPFKIP

telah ditransposisi ke dalam bentuk skalogram ini dapat memudahkan peneliti menganalisis respon yang tidak biasa diberikan oleh responden. Responden dengan kode 013TYK memberikan jawaban "Jarang Melaksanakan" dengan ditandai adanya skor 2 pada pernyataan nomor 10, artinya kemampuan dalam mengimplementasikan pernyataan nomor 10 ini masih kurang dibandingkan dengan responden yang lain. Selain itu, terdapat beberapa responden yang berindikasi memiliki kompetensi yang sama dalam pemahaman dan pengimplementasian ESD pada domain fasilitas pembelajaran, ditandai dengan jawaban responden memiliki pola sama. Pada responden dengan kode 014RUK $=024 \mathrm{TXD}$, 002RDX = 004RUD, 006RUD = 008RND, dan 001TWD $=005$ TND.

\section{E. Analisis Bias Kategori Guru Kelas Rendah dan Guru Kelas Tinggi}

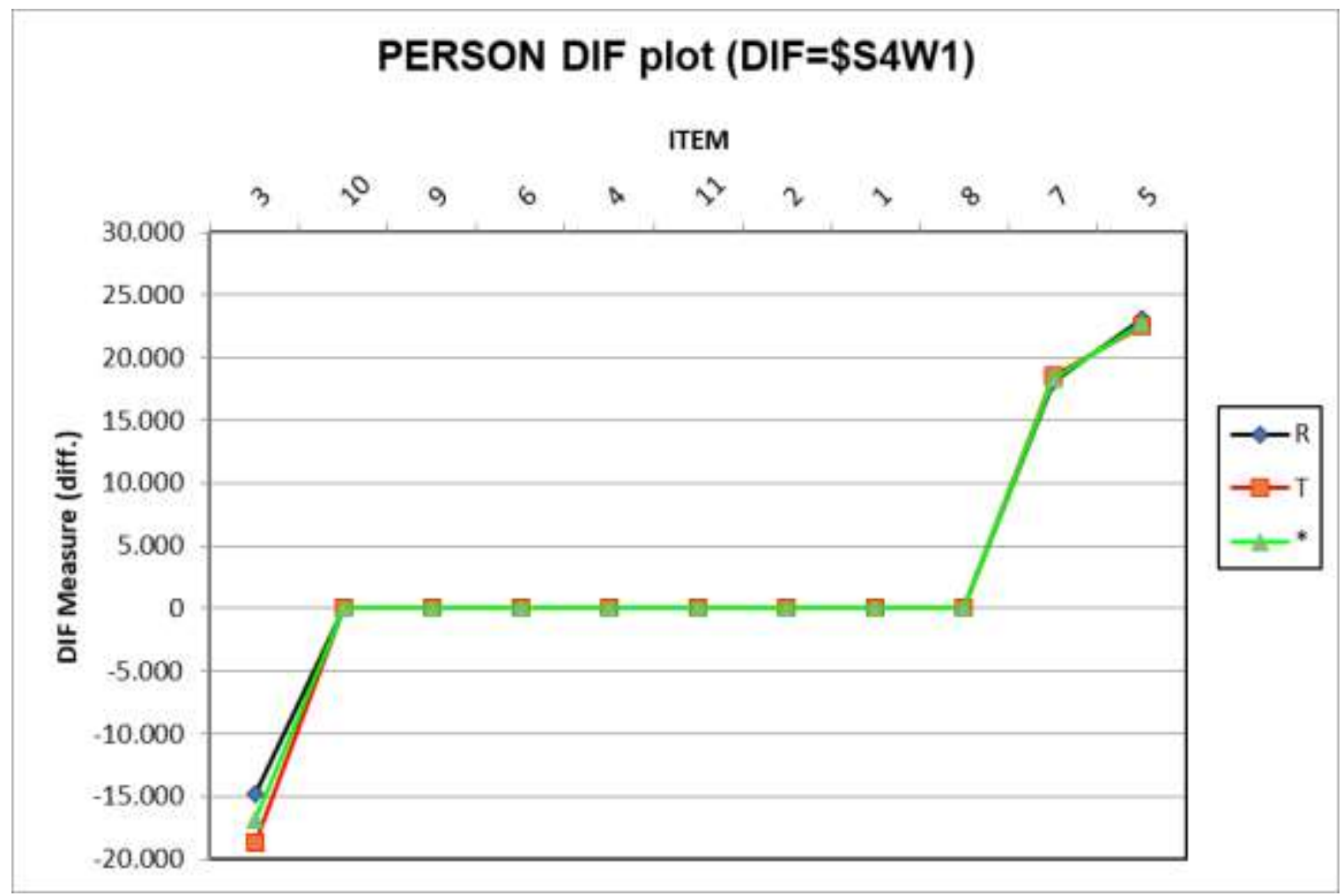

Gambar 5. Bias Kategori Guru Kelas Rendah dan Guru Kelas Tinggi

Dari grafik tersebut menunjukkan bahwa hasil jawaban dari responden yaitu guru kelas rendah dan kelas tinggi berada pada titik yang sama. Hanya saja pada pernyataan nomor 3 , ada sedikit kebiasan masalah pada item tersebut yang mempengaruhi jawaban dari guru kelas tinggi maupun kelas rendah. Selain itu, 10 pernyataan lainnya tidak ada permasalahan dari responden yang artinya pernyataan yang diajukan mengenai kompetensi guru berbasis ESD pada domain fasilitas pembelajaran bisa diterima oleh responden dengan baik.

Grafik tersebut juga menggambarkan pernyataan yang mudah dilaksanakan hingga tersulit. Pada pernyataan nomor 5 berindikasi menjadi pernyataan yang sulit dari 11 pernyataan, karena berada pada kurva tertinggi (membahas mengenai guru yang memfasilitasi pembelajaran dengan cara berkolaborasi 
bersama dengan para ahli bidang masing masing, misalnya seperti pengrajin kayu, dll, dengan memanfaatkan benda yang sudah tidak terpakai lagi menjadi produk yang memiliki nilai). Dengan demikian, guru - guru masih jarang memfasilitasi pembelajaran yang berkolaborasi bersama ahli di bidang masing masing, banyak faktor yang bisa membuat mereka belum mengimplementasikan hal tersebut, sehingga saat mengisi angket penelitian banyak yang memilih "Tidak Melaksanakan", kemudian menjadikan pernyataan nomor 5 menjadi sulit karena pada kenyataan di lapangan guru - guru belum melaksanakannya.

\section{F. Analisis Bias Lama Masa Kerja Guru}

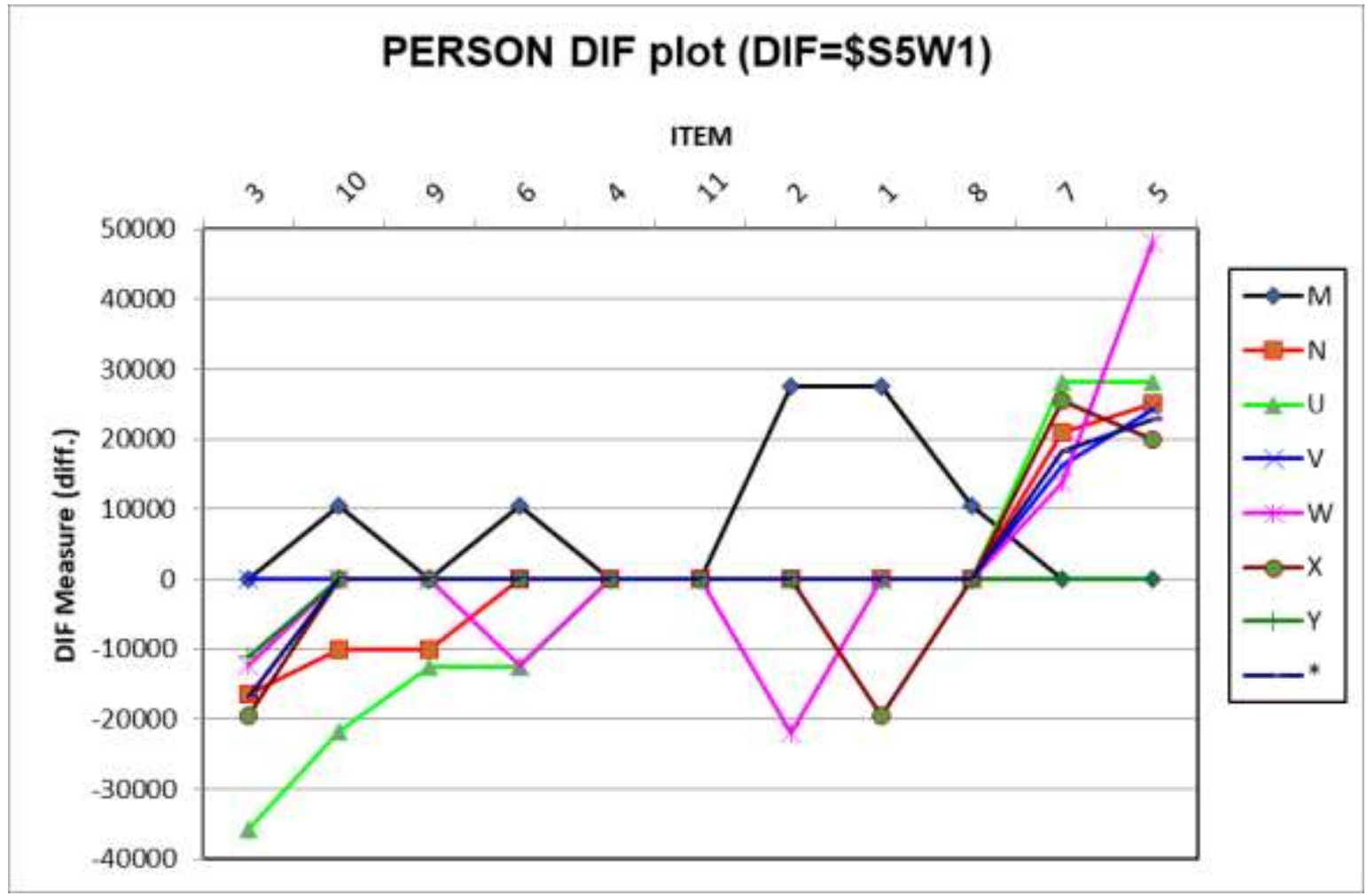

Gambar 6. Bias Lama Masa Kerja Guru

Terdapat kode lama masa kerja yang digunakan oleh peneliti, yaitu M ( $0-5$ tahun $)$, $\mathrm{N}$ (6 -10 tahun), U (11 - 15 tahun), V (16 - 20 tahun), W (21 - 25 tahun), X (26 - 30 tahun), Y (31 - 35 tahun). Dari grafik tersebut menginformasikan bahwa pernyataan nomor 4 dan 11 yang tidak ada masalah terhadap lama masa kerja responden berdasarkan jawaban yang telah diberikan. Namun, sembilan pernyataan lainnya belum bisa mewakili dan menggambarkan kualitas kompetensi guru berbasis ESD pada domain fasilitas pembelajaran berdasarkan lama masa mengajar dari responden. Artinya, lama masa mengajar dari responden belum tentu bisa mengukur pemahaman yang baik dan pengimplementasian yang baik pula.

Hal ini didukung dengan adanya data dari Gambar 3, bahwa responden dengan pemahaman dan pengimplementasian ESD pada domain fasilitas pembelajaran yang baik dicapai oleh responden dengan lama masa mengajar berbeda, yaitu 11 tahun dan 27 tahun. Dengan kata lain, untuk melihat kualitas 
dari guru mengenai pemahaman dan pengimplementasian ESD pada domain fasilitas pembelajaran dalam hal lama masa mengajar tidak cukup hanya mengisi angket yang diberikan oleh peneliti saja. Tentu, banyaknya pengalaman yang dimiliki oleh seorang guru tidak lepas dari lamanya masa kerja yang dimiliki guru tersebut (Hasan,
2015). Namun, pemahaman dan pengalaman seseorang akan berbeda - beda, meskipun dalam rentang waktu yang sama. Jadi tidak cukup jika menentukan kualitas guru hanya dari lamanya masa kerja guru tersebut.

\section{G. Analisis Bias Domisili}

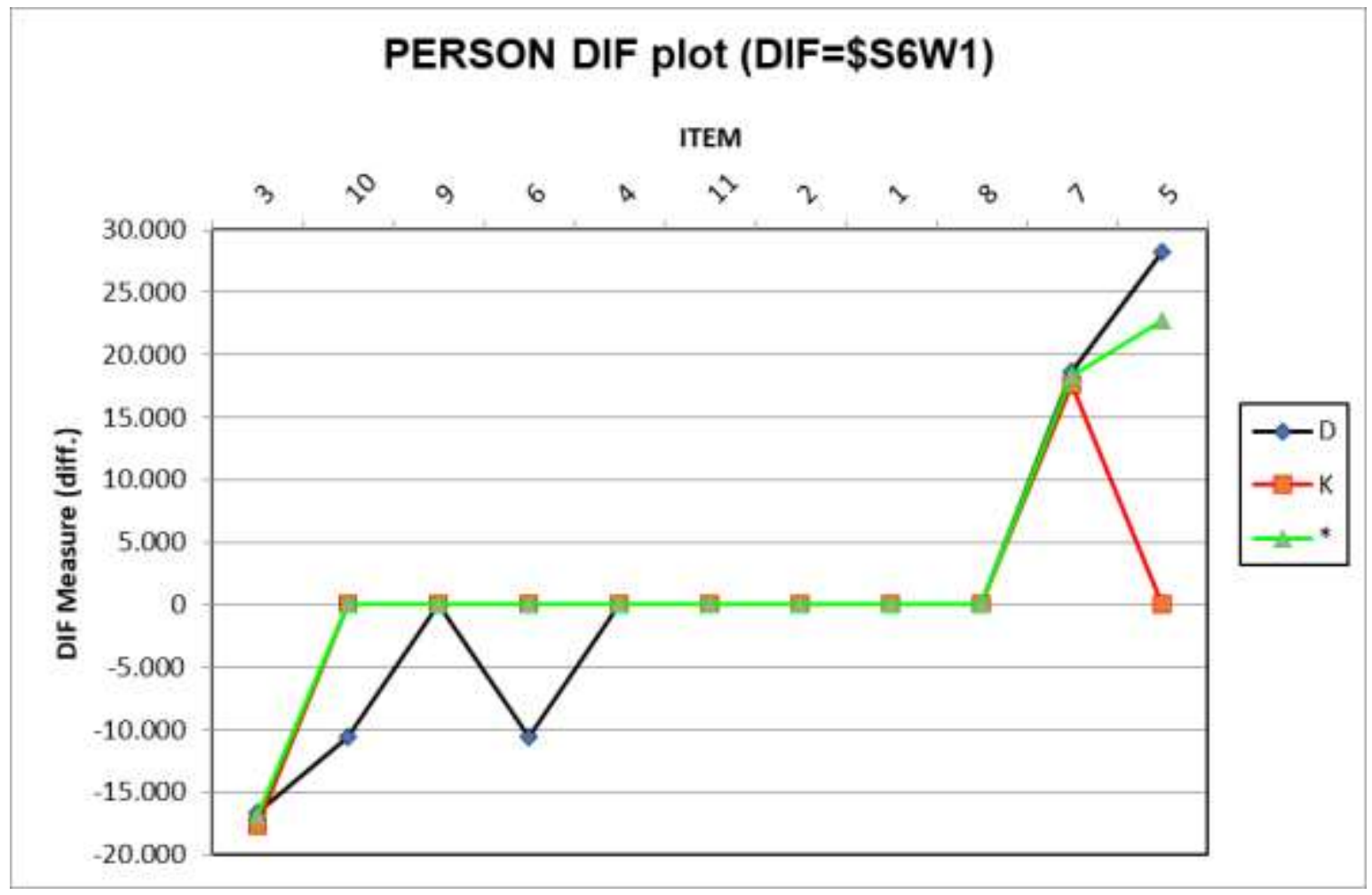

Gambar 7. Bias Domisili

Faktor geografis menjadi hal yang penting untuk menjadi pertimbangan diberbagai aspek (Sagitaningrum \& Frisko, 2016), termasuk dalam penelitian ini. Dari Gambar 7, diperoleh informasi bahwa grafik tersebut menggambarkan item dalam penyataan - pernyataan yang diberikan oleh peneliti lebih mudah dikerjakan oleh Sekolah Dasar (SD) yang bertempatan di kota, hal ini dibuktikan melalui kurva yang tidak berada pada titik semestinya hanya pada pernyataan nomor 5. Sedangkan untuk Sekolah Dasar (SD) yang bertempatan di kabupaten ada beberapa item pernyataan dianggap sulit untuk dilakukan oleh responden yaitu pernyataan nomor 10, 6 dan 5. Artinya kompetensi guru berbasis ESD pada domain fasilitas pembelajaran lebih mudah diterapkan di Sekolah Dasar yang bertempatan di kota. Hal ini menunjukkan bahwa, fasilitas di kota sudah cukup mendukung pembelajaran yang mengarahkan pada konsep ESD terutama domain fasilitas pembelajaran. Namun, meskipun di kabupaten mengalami sedikit keterbatasan mengenai hal - hal dalam memberikan fasilitas mengajar yang tidak sama seperti di kota, tetapi guru bisa mengoptimalkan sumber daya yang ada di 
lingkungan sekitar, sehingga peserta didik masih mendapatkan pelayanan yang terbaik dari guru sebagai fasilitator pembelajaran.

\section{SIMPULAN DAN REKOMENDASI}

Sebanyak 25 guru di sembilan Sekolah Dasar (SD) telah menjadi responden dengan mengisi angket yang diberikan oleh peneliti mengenai kompetensi guru berbasis Education for Sustainable Development pada domain fasilitas pembelajaran. Berdasarkan data yang telah diolah melalui aplikasi Winsteps dengan menggunakan rasch model, item atau instrumen penelitian yang telah dibuat oleh peneliti memiliki nilai reliabilitas sebesar 0,90 termasuk kedalam kategori bagus, sedangkan untuk reliabilitas responden sebesar 0,56 termasuk kategori lemah. Artinya instrumen yang telah dibuat sudah bagus namun konsistensi jawaban dari responden masih kurang.

Pada Tabel 1, diperoleh data mengenai kesulitan pernyataan untuk dilaksanakan. Pernyataan tersulit ada pada nomor 5 dan pernyataan termudah ada pada nomor 3 . Kemudian Gambar 3, dapat menginformasikan mengenai responden atau guru terbaik dalam pemahaman dan pengimplementasian kompetensi guru berbasis ESD pada domain fasilitas pembelajaran ialah responden dengan kode 014RUK dan 024TXD. Namun, disamping itu pula tidak ada guru yang berada dibawah rata - rata pada logit 0.00. Artinya, guru - guru yang menjadi responden mengetahui dan sudah mengimplementasikan fasilitas pembelajaran berbasiskan ESD. Hanya saja, mereka tidak mengetahui secara gagasannya bahwa hal tersebut adalah konsep ESD pada domain fasilitas pembelajaran, baik guru yang di kabupaten atau kota, guru kelas rendah atau tinggi, guru dengan masa lama mengajar sebentar atau lama, mereka sudah mengimplementasikannya dengan baik.

Sehingga perlu adanya, pengenalan kepada guru - guru mengenai kompetensi guru berbasis ESD, dan sekaligus mengingat bahwa ini adalah program dunia yang menjadikan setiap individu memiliki peran aktif untuk pembangunan berkelanjutan. Dalam dunia pendidikan tentunya guru memiliki peran penting di dalamnya. Penting bagi seorang guru selalu memperbaharui cara mengajar dan memfasilitasi peserta didik sebaik mungkin, sebab zaman akan semakin maju dan tentunya tantangan dimasa depan akan semakin sulit. Hal - hal yang perlu diperhatikan untuk penelitian selanjutnya ialah penyusunan atau pembuatan instrumen penelitian. Semakin baik instrumen yang dibuat maka akan semakin baik pula data yang akan diperoleh. Selain itu, diskusi dengan tim penelitian atau bersama para ahli di bidangnya akan sangat membantu.

\section{UCAPAN TERIMA KASIH}

Terima kasih kepada dosen pembimbing dalam penelitian dan penyusunan artikel ini, kepada Focus Group Discussion $(F G D)$ bersama tim research ESD yang telah membantu dari awal hingga akhir penelitian, kepada orang tua yang selalu mendoakan dan teman - teman yang memberikan semangat.

\section{DAFTAR PUSTAKA}

Abdul, D., Lidinillah, M., Aprilia, M., Suryana, D., \& Ahmad, A. B. (2020). Development of Creativity Instrument through Rasch Model Analysis. 8(4), 1620-1627. https://doi.org/10.13189/ujer.2020.08045 5

Glavic, P. (2020). Identifying key issues of education for sustainable development. Sustainability (Switzerland), 12(16). https://doi.org/10.3390/su12166500

Hasan, R. (2015). Pengaruh Masa Kerja Dan Pendidikan Guru Terhadap Kinerja Guru Sdn Sukabumi 10 Kota. Jurnal Penelitian Dan Pendidikan IPS (JPPI), 9(2), 12191230.

ejournal.unikama.ac.id/index.php/JPPI/ar ticle/view/1664

Hoffmann, T., \& Siege, H. (2018). What is Education for Sustainable Development (ESD)? Human Development, 1(8), 1-6. 
http://www.esd-expert.net/files/ESD-

Expert/pdf/Was_wir_tun/Lehr- und Lernmaterialien/What_is_Education_for_ Sustainable_Development.pdf\%0Ahttp:// www.esd-expert.net/teaching-andlearning-materials.html.

Jagtap, P. (2016). Teachers role as facilitator in learning. Scholarly Research Journal, 3(17), 3903-3905.

Japan National Commission for UNESCO. (2016). A Guide to Promoting ESD (Education for Sustainable Development). March, 49. http://www.mext.go.jp/component/englis h/__icsFiles/afieldfile/2016/11/21/13796 53_01_1.pdf

Mustadi, A., \& Senen, A. (2018). Pendidikan Sekolah Dasar. http://library1.nida.ac.th/termpaper6/sd/2 554/19755.pdf

Poekert, P. (2011). The pedagogy of facilitation: Teacher inquiry as professional development in a Florida elementary school. Professional Development in Education, 37(1), 19-38. https://doi.org/10.1080/19415251003737 309

Priatna, B. A. (2008). Instrumen penelitian. 3(November), 1-22.

Rahmawati, M., \& Suryadi, E. (2019). Guru sebagai fasilitator dan efektivitas belajar siswa. Jurnal Pendidikan Manajemen Perkantoran, 44(1), 49. https://doi.org/10.17509/jpm.v4i1.14954.

Sagitaningrum, D., \& Frisko, D. (2016). Corporate Social Responsibility: Keterkaitan Letak Geografis Terhadap Desain Program dan Pelaporan Perusahaan. Jurnal Ekonomi Dan Bisnis, 18(3), 43. https://doi.org/10.24914/jeb.v18i3.283
Sumintono, B., \& Widhiarso, W. (2013). Aplikasi Model Rasch Untuk Penelitian Ilmu-Ilmu Sosial.

Sumintono, B., \& Widhiarsono, W. (2015). Aplikasi Pemodelan Rasch pada Assessment Pendidikan (Bambang Trim (ed.); I). Trim Komunikata.

UNESCO. (2017). Education for Sustainable Development Goals Learning Objectives.

UNESCO. (2018). Integrating Education for Sustainable Development (ESD) in Teacher Education in South-East Asia. http://library1.nida.ac.th/termpaper6/sd/2 554/19755.pdf

UNESCO. (2020). Guide for the Effective Dissemination of the Asia-Pacific ESD Teacher Competency Framework. 